\title{
HISTOLOGICAL AND BIOCHEMICAL EFFECTS INDUCED BY SUBLETHAL DOSES OF Bothrops jararacussu VENOM IN MICE
}

\author{
ZENI A. L. B. (1), BECKER A. (1), KRUG M. (1), ALBUQUERQUE C. A. C. (1)
}

(1) Department of Natural Sciences, Center of Exact and Natural Sciences, Regional University of Blumenau, Blumenau, Santa Catarina State, Brazil.

ABSTRACT: Snake venom is characterized by hemorrhagic, coagulant, proteolytic and myotoxic activities which in Bothrops jaracussu venom are related to intraspecific variations. In the present study, female Swiss mice were divided into two groups: treated with $25 \mu \mathrm{g}$ or $50 \mu \mathrm{g}$ venom. These were subdivided into three groups of six animals each, according to blood collection: 2, 4 or $24 \mathrm{~h}$ after venom injection. Animals were anesthetized using diethyl-ether inhalation and $1 \mathrm{ml}$ of blood was collected by heart puncture. Then, the following organs were removed: spleen, skeletal muscle, kidneys, liver and lungs; histological sections were obtained and stained with hematoxylin-eosin (HE). The following biochemical parameters were analyzed: aspartate aminotransferase (AST/GOT), alanine aminotransferase (ALT/GPT), total lactate dehydrogenase (LDH), glucose, creatinine and urea levels, and total protein content. Results showed significant alterations in AST, LDH, glucose and urea levels, and total protein content, as well as important tissue alterations in the liver, kidneys and lungs. It could be concluded that, even using sublethal doses of venom, there were significant changes in almost all the tested biochemical parameters as well as tissue alterations in the kidneys and lungs.

KEY WORDS: Bothrops jararacussu, snake venoms, sublethal doses, in vivo studies, biochemical parameters, histopathological alterations.

CONFLICTS OF INTEREST: There is no conflict.

\section{CORRESPONDENCE TO:}

ANA LÚCIA BERTARELLO ZENI, Departamento de Ciências Naturais, Centro de Ciências Naturais e Exatas, Universidade Regional de Blumenau, Rua Antônio da Veiga, 140, 89012-900, Blumenau, SC, Brasil. Phone: 55214733210272.

E-mail: anazeni@furb.br. 


\section{INTRODUCTION}

In the Brazilian territory, snakes of the Bothrops genus account for a total of twenty species and are responsible for $90 \%$ of the snakebite accidents. According to the Ministry of Health, more than 17000 bothropic accidents occur every year in the country, with a fatality rate of approximately $0.6 \%$ treated cases.

Bothropic venom is very complex. It contains twenty or more different compounds and over $90 \%$ of its dry weight is constituted of proteins encompassing a large variety of components such as lecithin, metalloproteinases, serine proteinases, disintegrins, phospholipases and peptides such as bradykinin and angiotensin (7). Non-protein fractions are represented by carbohydrates, lipids, metals, and biogenic enzymes (10).

The venom from Bothrops snakes presents a complex mixture of toxins with different toxic or enzymatic properties. Proteases apparently act by degrading tissue proteins in a non-specific manner (26) and by cleaving plasmatic proteins through hydrolysis, interfering in the homeostasis of the organism $(16,21)$. Such substances can have hemorrhagic, coagulant, proteolytic and myotoxic activities that result in inflammatory process and tissue destruction during damage to blood vessel walls or in pain, edema, ecchymosis, abscess formation, and necrosis $(12,18,20,23,27)$.

The aim of the present work was to study in mice the local and systemic effects of sublethal doses of venom from $B$. jararacussu specimens commonly found in tropical forests of Santa Catarina, Brazil. Histological alterations as well as changes in serum levels of several enzymes and metabolites were analyzed.

\section{MATERIALS AND METHODS}

\section{Venom}

Venom was obtained from an adult $B$. jararacussu in the animal facility of the Regional University of Blumenau, Santa Catarina, Brazil. It was preserved at $-20^{\circ} \mathrm{C}$ until use, when the lyophilized venom was dissolved in phosphate buffered saline (PBS), pH 7.2, to obtain the doses $25 \mu \mathrm{g}$ and $50 \mu \mathrm{g}$.

\section{Animals}

Female Swiss mice (20-25g) were divided into two groups: treated with $25 \mu \mathrm{g}$ or $50 \mu \mathrm{g}$ venom; these sublethal doses were also used by Feitosa Neto (8). Groups were 
subdivided into three subgroups of six animals each. The fasted animals were intraperitoneally (i.p.) injected with venom and anesthetized through diethyl-ether inhalation after 2, 4 or $24 \mathrm{~h}$ for blood collection (about $1 \mathrm{ml}$ ) by cardiac puncture. Control animals received $100 \mu$ PBS, i.p. The present experiment was approved by the Committee of Ethics in Research with Animals 009/04.

\section{Histological Analysis}

Animals were sacrificed by ether inhalation and the following organs were removed: spleen, skeletal muscle, kidneys, liver and lungs, which were then fixed in $10 \%$ formalin, dehydrated and included in paraffin wax for $5 \mu \mathrm{m}$ sections that were stained with HE and observed under light microscope.

\section{Biochemical Analysis}

After blood collection, serum was separated by centrifugation and the following tests were carried out: AST and ALT levels determination, which was based on the formation of 2,4-dinitrophenyl phosphate; LDH levels determination, which was based on the formation of NADH (one unit results in the formation of $1 \mu \mathrm{mol}$ NADH per minute); total protein content determination using the Biuret method; glucose levels determination, which was based on the formation of quinoneimine dye; creatinine levels determination using the creatinine picrate method; and urea levels determination, which was based on the formation of indophenol blue, using a BioSystems BTS 310 photocolorimeter and Standard BioSystems reagents.

\section{Statistical Analysis}

Data of normal distribution were expressed as means \pm S.E.M. The values obtained were evaluated by analysis of variance (ANOVA), followed by sufficient post hoc tests. Each treatment was considered an independent variable. In all cases, the considered statistical significance level was $p<0.05$. The Graph Pad Prism ${ }^{\circledR}$ program, version 3.0, was used for obtaining graphs and statistical analysis of the results. 


\section{RESULTS}

\section{Histological Findings}

Figure 1 shows some tissues of organs from treated animals, compared with those from control animals. Cellular alteration was verified on the lungs, kidneys and liver, but not in the spleen or skeletal muscle. Figure 1A shows a histological section of liver $4 \mathrm{~h}$ after injection of $25 \mu \mathrm{g}$ venom. There are leukocyte aggregations near blood vessels and evident vascular congestion. Figure 1B displays a histological section of liver from a control mouse. The center-lobe vein has normal morphological characteristics. Figures 1C and 1D present lung sections $4 \mathrm{~h}$ after injection of $25 \mu \mathrm{g}$ venom. Cellular alterations were noticed due to the presence of inflammatory cells in the inter-alveolar spaces and inside pulmonary alveoli as well as abnormal accumulation of erythrocytes and leukocytes. Control group presented normal lung characteristics (Figure 1E).

Figures $1 \mathrm{~F}$ and $1 \mathrm{G}$ show the cortical region of kidneys $4 \mathrm{~h}$ after injection of 50 and $25 \mu \mathrm{g}$ venom, respectively. Evident glomerular alterations were noticed as renal glomeruli necrosis and vascular congestion (Figure 1F). A renal corpuscle with leukocyte infiltration was observed in the glomerular capillaries and, more discretely, in the periarterial areas and between the renal tubules (Figure 1G). The renal corpuscle and the renal tubule in the control group (Figure $1 \mathrm{H})$ were normal.

\section{Venom-Induced Biochemical Alterations}

An increase in AST activity was observed $4 \mathrm{~h}$ after injection of $25 \mu \mathrm{g}$ venom, compared with the control group; $2 \mathrm{~h}$ after injection of $50 \mu \mathrm{g}$ venom, it was also significant (Figure 2). On the other hand, ALT levels did not change significantly with venom doses at each time interval (results not shown). Serum levels of LDH were high at all studied periods and $50 \mu \mathrm{g}$ venom caused significant increase, whereas $25 \mu \mathrm{g}$ caused significant changes only at $2 \mathrm{~h}$ (Figure 3 ).

Regarding the enzymatic determination of total proteins, the main increases were observed with $50 \mu \mathrm{g}$ at $4 \mathrm{~h}$ and $24 \mathrm{~h}$ and were considered extremely significant (Figure 4). Serum levels of glucose with $50 \mu \mathrm{g}$ at $2 \mathrm{~h}$ were considered very significant compared with the control group (Figure 5). 
Creatinine levels were not significant in relation to the control group (results not shown). Urea levels at $2 \mathrm{~h}$ and $4 \mathrm{~h}$ with $50 \mu \mathrm{g}$ venom were extremely significant compared with control (Figure 6).
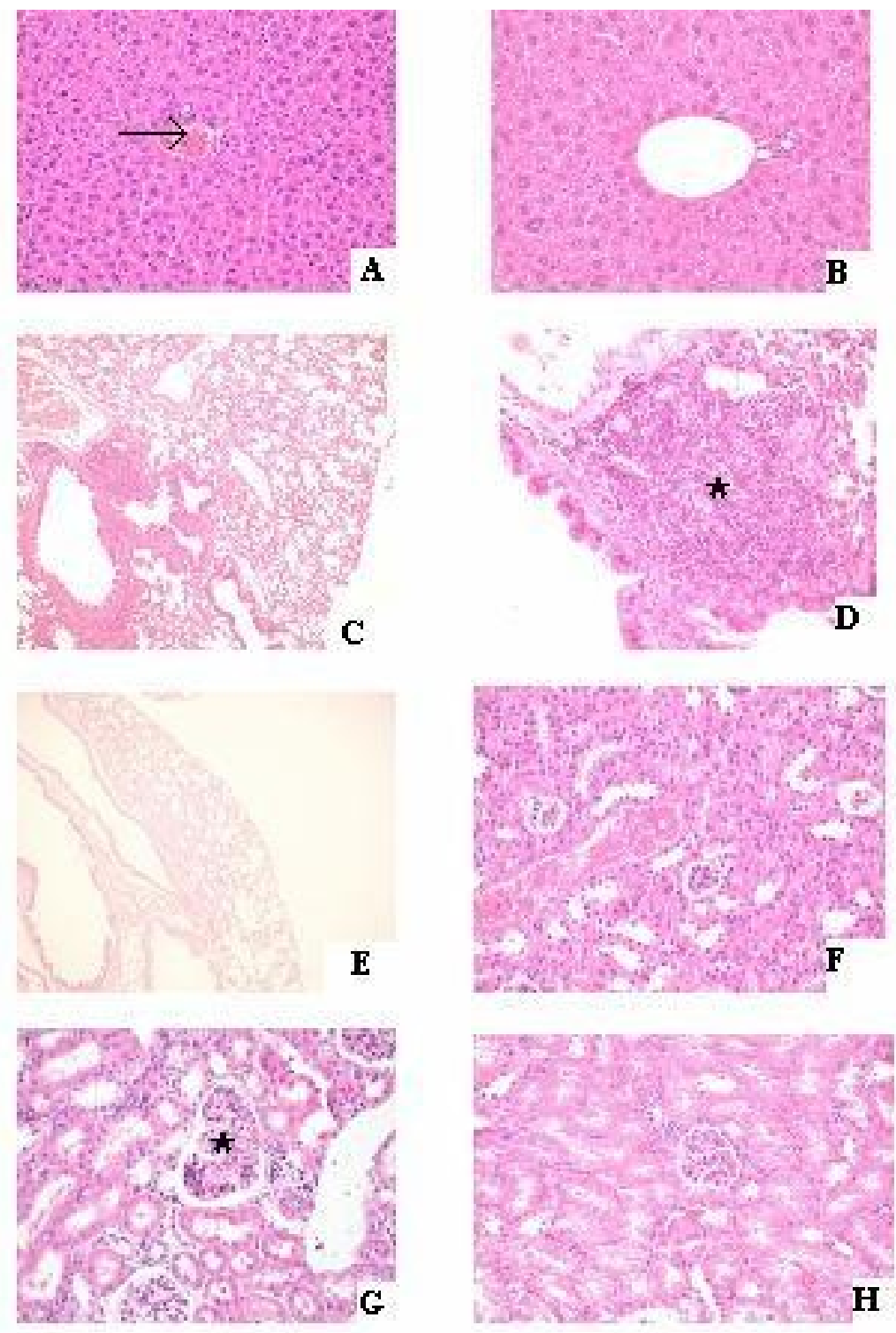

Figure 1. A: Center-lobe vein in the liver of an animal treated with $25 \mu \mathrm{g}$ venom (4h); B: Liver of a control animal (4h); C and D: Alveolar spaces and pulmonary alveoli in the lungs of animals treated with $25 \mu \mathrm{g}$ venom (4h); E: Lung of a control animal; $F$ and G: Cortical region in the kidneys with glomeruli of animals treated with $50 \mu \mathrm{g}$ and $25 \mu \mathrm{g}$ venom, respectively (4h); $\mathrm{H}$ : Kidney of a control animal (4h). 400X magnification.

$\rightarrow$ : Vascular congestion.

*: Inflammatory cells. 


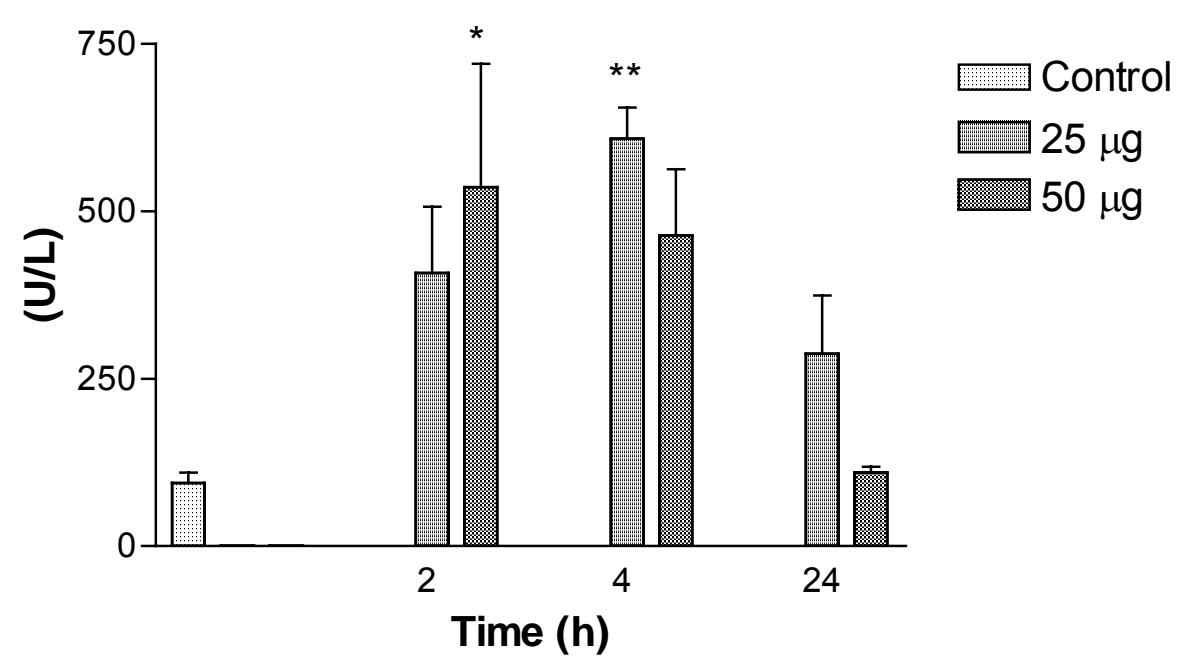

Figure 2. Variations in aspartate aminotransferase (AST/GOT) levels in mice intraperitoneally injected with 25 or $50 \mu \mathrm{g}$ of Bothrops jararacussu venom diluted with $0.1 \mathrm{ml}$ PBS. Each bar represents the mean and vertical lines, the standard error of mean (S.E.M.) of results obtained from 6 animals.

Asterisks denote the significance levels when compared with control group: ${ }^{*} p<0.05$, ** $p<0.01$.

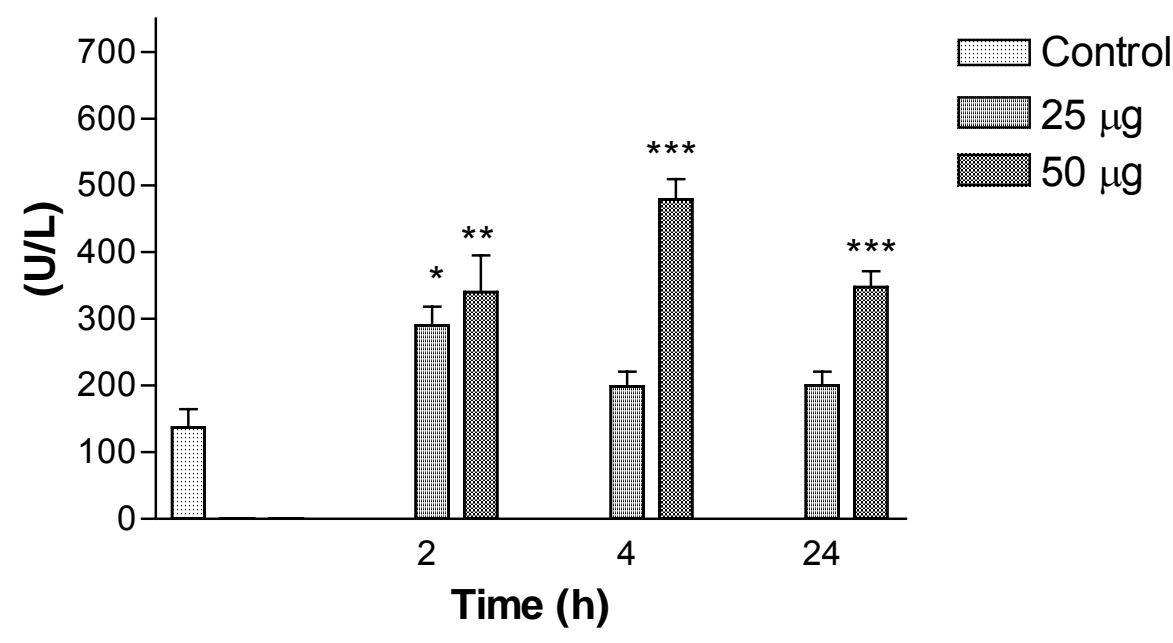

Figure 3: Variations in lactate dehydrogenase (LDH) levels in mice intraperitoneally injected with 25 or $50 \mu \mathrm{g}$ of Bothrops jararacussu venom diluted with $0.1 \mathrm{ml}$ PBS. Each bar represents the mean and vertical lines, the standard error of mean (S.E.M.) of results obtained from 6 animals.

Asterisks denote the significance levels when compared with control group: * $p<0.05$, ${ }^{* *} p<0.01,{ }^{* * *} p<0.001$. 


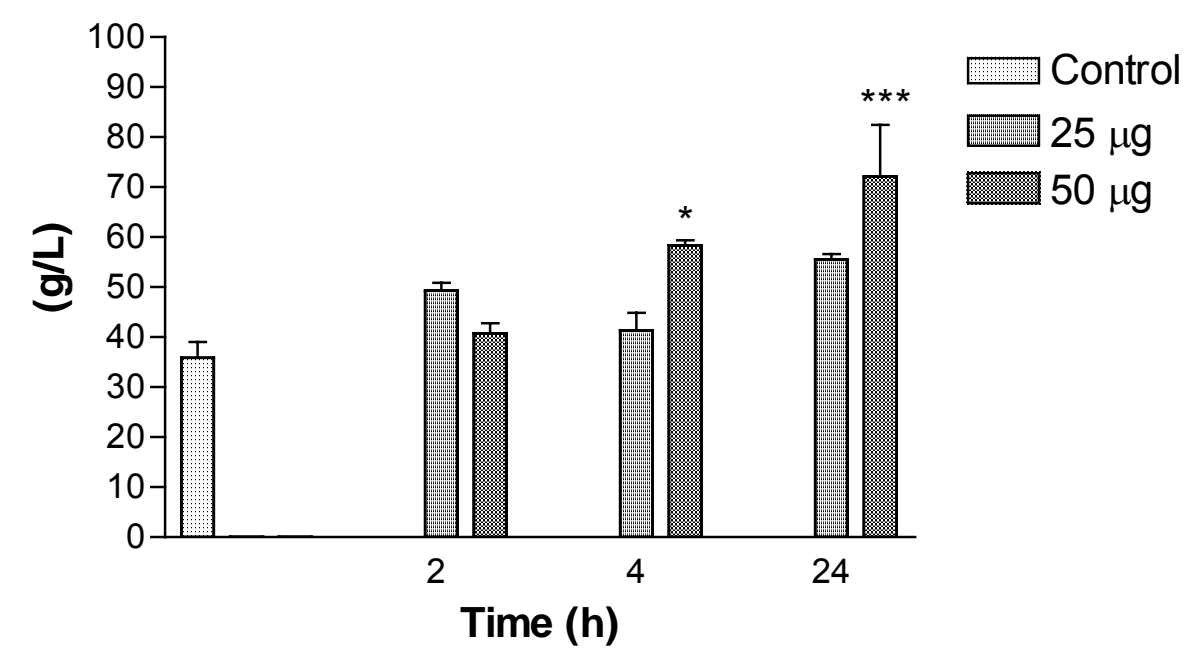

Figure 4. Variations in total protein levels in mice intraperitoneally injected with 25 or $50 \mu \mathrm{g}$ of Bothrops jararacussu venom diluted with $0.1 \mathrm{ml}$ PBS. Each bar represents the mean and vertical lines, the standard error of mean (S.E.M.) of results obtained from 6 animals.

Asterisks denote the significance levels when compared with control group: * $p<0.05$, *** $p<0.001$.

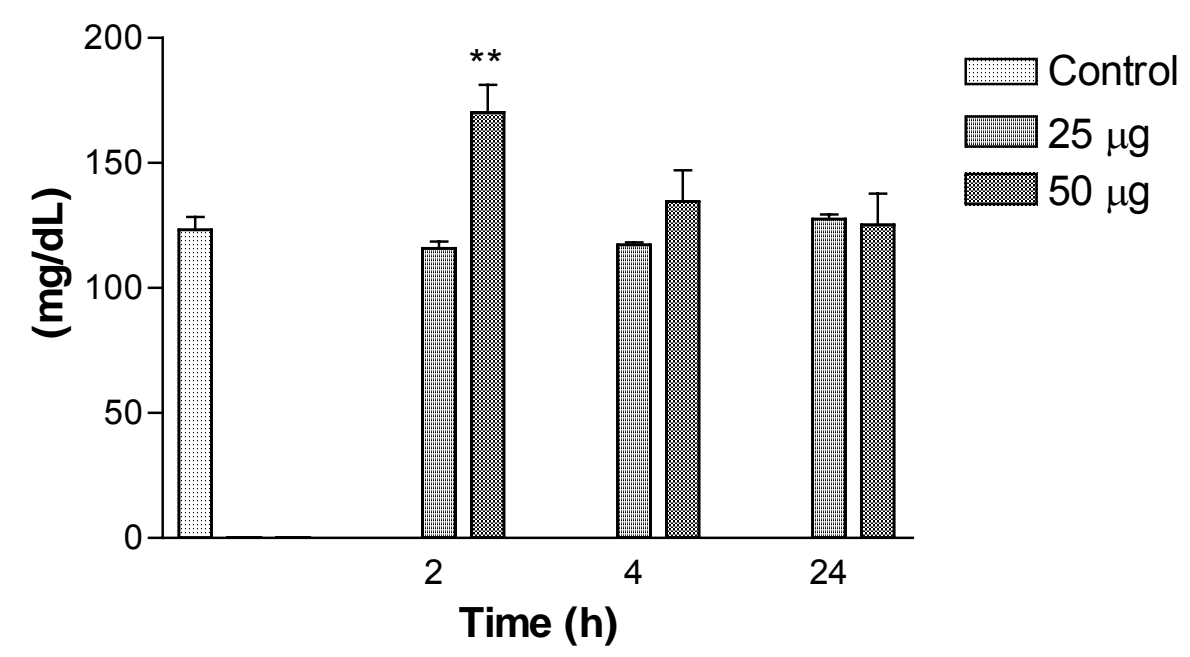

Figure 5. Variations in glucose levels in mice intraperitoneally injected with 25 or $50 \mu \mathrm{g}$ of Bothrops jararacussu venom diluted with $0.1 \mathrm{ml}$ PBS. Each bar represents the mean and vertical lines, the standard error of mean (S.E.M.) of results obtained from 6 animals.

Asterisks denote the significance levels when compared with control group: ** $p<0.01$. 


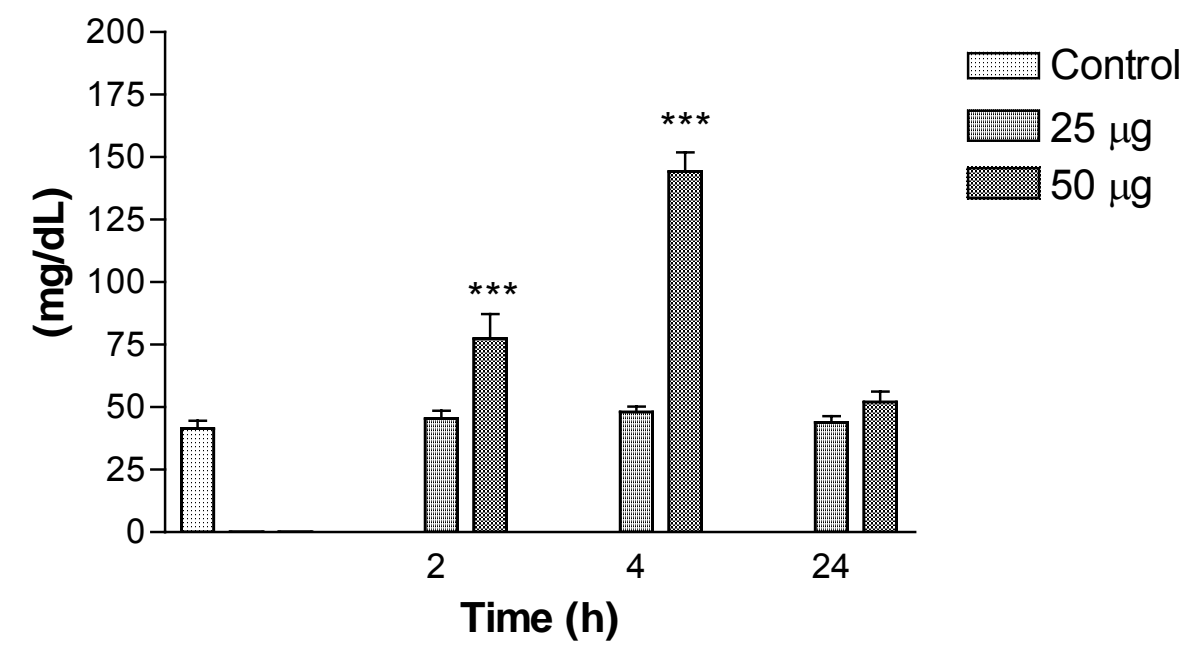

Figure 6: Variations in urea levels in mice intraperitoneally injected with 25 or $50 \mu \mathrm{g}$ of Bothrops jararacussu venom diluted with $0.1 \mathrm{ml}$ PBS. Each bar represents the mean and vertical lines, the standard error of mean (S.E.M.) of results obtained from 6 animals.

Asterisks denote the significance levels when compared with control group: *** $\mathrm{p}<0.001$.

\section{DISCUSSION}

Bothrops jararacussu has one of the most lethal venoms among Bothrops species. In a review of 29 snakebite accidents caused by $B$. jararacussu, several patients developed shock and oliguria few hours after the bite and three victims died (18).

Pathological alterations (local effects provoked by snakebites) have been extensively reported due to the large variety of enzymes and other compounds present in snake venoms. However, pathophysiological alterations, the role of enzymes, and the systemic complications induced by sublethal doses are not very clear for $B$. jararacussu venom.

Figures $1 \mathrm{~A}-\mathrm{H}$ present important information about tissue alterations in some organs of animals treated or not with venom, corroborating the obtained serum data; however, such alterations were not dose and time-dependent. In Figure 1A, tissue alterations in the liver are visible as there is high concentration of perivascular leukocytes, indicating an inflammatory process, besides intense vascular congestion in the center-lobular vein.

Alterations in striated muscle were not visible, probably because the chosen envenomation route (i.p.) used a site with many capillaries carrying venom for all the 
system, not restricting it to only one site. A snakebite accident is more similar to subcutaneous injection of venom $(15,17)$, allowing the observation of systemic signs and modified tissue characteristics in the liver and pulmonary parenchyma, together with renal hemorrhage. Zamunér et al. (28) also reported effective myonecrosis by $B$. jararacussu and B. moojeni venoms.

Hemorrhagic toxins and other components impair or increase the vascular permeability of endothelial cells and the basal membrane, allowing the blood to escape towards the neighboring tissues $(2,25)$. Liver cells presented altered metabolic activity, which was verified by blood biochemical analysis, suggesting hepatocyte death. Inflammatory focus was observed in all the liver parenchyma, principally in the perivascular region.

The metalloproteinases found in the venom presented hemorrhagic effect and were capable of inducing the release of inflammation mediators such as cytokines, intensifying the inflammatory response (25), which may justify the occurrence of a large quantity of defense cells in the pulmonary parenchyma. This effect collaborates to coagulation in microcirculation, promoting disseminated intravascular coagulation, which leads to hemorrhage and pulmonary edema.

In lung histological sections, morphological alterations were evident with $25 \mu \mathrm{g}$ venom, which caused increased inflammatory cells and intra-alveolar erythrocytes as well as edema, indicating compromised pulmonary functions (Figure 1D). The increase in pulmonary damage depends on the local lesion but its evolution is not frequent in human envenomation by $B$. jararacussu (4).

In animals treated with 25 or $50 \mu \mathrm{g}$ of venom, histological analysis of the kidneys confirmed the diagnosis of increased renal workload resultant from the high protein levels observed in serum analysis, which can lead to cellular and/or tissue alterations that compromise the organ function and cause renal glomeruli destruction, vascular congestion, microvascular hemorrhagic lesion, and leukocyte aggregation.

Renal failure is the major complication in envenomation by $B$. jararacussu and other Bothrops species (18). Cortical renal necrosis can be related to intravascular coagulation or directly to renal endothelium or even vasospasm toxic effect (1). In the liver, alterations were not clearly visible under the microscope and were only verified by leukocyte aggregation and intravascular coagulation. Figure 2 shows that serum levels of AST significantly increased, indicating hepatic damage (24) as 
observed in hepatitis, other hepatic diseases associated with necrosis after administration of some classes of medication or after myocardial infarction, diseases of the muscular-skeletal system, acute pancreatitis, hemolytic diseases, and others $(5,11)$.

The levels of ALT were also altered, although not significantly. The fact that AST levels increased more with dose than ALT levels indicates not only cell destruction, but also mitochondrial disruption (3). The results obtained for AST and ALT levels were similar to those obtained by Chavez et al. (6) with $B$. asper, which in turn were different from those reported by Teibler et al. (27) with B. alternatus: all two parameters significantly changed.

Regarding $\mathrm{LDH}$, the increase in its activity was significant at 2, 4 and $24 \mathrm{~h}$ with $50 \mu \mathrm{g}$ and only at $2 \mathrm{~h}$ with $25 \mu \mathrm{g}$ venom; in the study of Chavez et al. (6), it differed only at 6h. LDH activity is increased in hepatic diseases, renal alterations, myocardial infarction, and progressive muscular dystrophy and in any case of hemolysis $(5,11)$. These alterations and ALT levels indicated skeletal-muscle (6) and, possibly, myocardial damage (3), which was also reported by Benvenuti et al. (4) about a woman bitten by $B$. jararacussu. The glucose levels observed in mice were within the normal range of $62-175 \mathrm{mg} / \mathrm{dl}$ (13).

Total protein content presented dose and time-dependent alterations and urea levels significantly increased, showing intense protein degradation, increased renal workload and liver necrosis. Renal damages with different types of lesions (glomerular, tubular, interstitial or vascular) increased urea serum levels (19).

Results suggested that the increase in total protein content and urea levels was related to the myotoxic $(14,18,22,23)$ and proteolytic activities $(4,9)$ of $B$. jararacussu venom and to the decrease in the liver activity. Milani et al. (18) described 29 snakebite accidents caused by this species, in which several patients developed shock and oliguria few hours after the bite. This also explains the data found in the present study.

\section{ACKNOWLEDGEMENTS}

This work was supported by Support Foundation of Scientific and Technological Research in Santa Catarina State (FAPESC), the authors thank Professor Andreia 
A. L. B. Zeni et al. HISTOLOGICAL AND BIOCHEMICAL EFFECTS INDUCED BY SUBLETHAL DOSES OF Bothrops jararacussu VENOM IN MICE. J. Venom. Anim. Toxins incl. Trop. Dis., 2007, 13, 3, p. 674

Janene de Oliveira Lima (in memorian) for the pathological analysis and Professor Alessandra Beirith for the general review of the paper.

\section{REFERENCES}

1 AMARAL CFS., SILVA OA., GODOY P., MIRANDA D. Renal cortical necrosis following Bothrops jararaca and B. jararacussu snakebite. Toxicon, 1985, 23, 877-85. 2 ARTASHES VA., SILVA VA. Histopathological changes induced by the venom of the snake Vipera raddei (Armenian adder). Toxicon, 2005, 47, 141-3.

3 BABCOCK JL., SUBER RL., FRITH CH., GEREN CR. Systemic effect in mice of venom apparatus extract and toxin from the brown recluse spider (Loxosceles reclusa). Toxicon, 1981, 19, 463-71.

4 BENVENUTI LA., FRANÇA OSF., BARBARO KC., NUNES JR., CARDOSO JLC. Pulmonary haemorrhge causing rapid death after Bothrops jararacussu snakebite: a case report. Toxicon, 2003, 42, 331-4.

5 BURTIS CA., ASHWOOD ER. Tietz Textbook of Clinical Chemistry. 5.ed. Philadelphia: WB Saunders, 2001.

6 CHAVES F., GUITIÉRREZ JM., LOMONTE B., CERDAS L. Histopathological and biochemical alterations induced by intramuscular injection of Bothrops asper (terciopelo) venom in mice. Toxicon, 1989, 27, 1085- 93.

7 CLISSA PB. Caracterização do efeito da jararagina sobre a produção e liberação de citocinas pró-inflamatórias em modelo murino. São Paulo: Universidade de São Paulo, Instituto de Ciências Biomédicas, 2002. 109p. [PhD Thesis].

8 FEITOSA NETO AC. Verificação da resposta imunológica do veneno de serpente Bothrops jararacussu frente ao inoculo de ovoalbumina em camundongos Swiss. Blumenau: Universidade Regional de Blumenau, 2003. 89p. [End of Course Paper Biological Sciences].

9 FRANCISCHETTI IMB., CASTRO HC., ZINGALLI RB., CARLINI CR., GUIMARÃES JA. Bothrops sp. Snake venoms: comparison of some biochemical and physiochemical properties and interference in platelet functions. Comp. Biochem. Physiol., 1998, 119C, 21-9.

10 FRANÇA FOS., CARDOSO JLC. Estudo retrospectivo da evolução de acidentes botrópicos. Rev. Soc. Bras. Med. Trop., 1987, 20, 56.

11 FRIEDMAN RB., YOUNG DS. Effects of disease on clinical laboratory tests. 3.ed. Washington: AACC Press, 1997. 
A. L. B. Zeni et al. HISTOLOGICAL AND BIOCHEMICAL EFFECTS INDUCED BY SUBLETHAL DOSES OF Bothrops jararacussu VENOM IN MICE. J. Venom. Anim. Toxins incl. Trop. Dis., 2007, 13, 3, p. 675

12 GUIMARÃES AQ., CRUZ-HÖFLING MA., FERREIRA DE ARAÚJO PM., BON C., LÔBO DE ARAÚJO A. Pharmacological and histopathological characterization of Bothrops lancelatus (Fer de lance) venom-induced edema. Inflamm. Res, 2004, 53, 284-91.

13 HARKNESS JE., WAGNER JE. Biologia e clínica de coelhos e roedores. 3.ed. São Paulo: Roca, 1993. 238p.

14 JORGE MT., RIBEIRO LA., O'CONNELL JL. Prognostic factors for amputation in the case of envenoming by snakes of the genus Bothrops (Viperidae). Ann. Trop. Med. Parasitol., 1999, 93, 401-8.

15 KAMIGUTI AS., THEAKSTON RDG., DESMOND H., HUTTON A. Systemic haemorrhage in rats induced by a haemorrhagic fraction from Bothrops jararaca venom. Toxicon, 1991, 29, 1097-105.

16 MATSUI T., FUGIMURA Y., TITANI $\mathrm{K}$ Snake venom proteases affecting haemostasis and thrombosis. Biochim. Biophys. Acta, 2000, 1477, 146-56.

17 MELO PA., HOMSI-BRANDEBURGO MI., GIGLIO JR., SUAREZ-KURTZ G. Antagonism of the myotoxic effects of Bothrops jararacussu venom and bothropstoxin by polyanions. Toxicon, 1993, 31, 285-91.

18 MILANI R., JORGE MT., CAMPOS FPF., MARTINS FP., BOUSSO A., CARDOSO JLC., RIBEIRO LA., FAN HW., FRANÇA FOS., SANO MARTINS IS., CARDOSO D., FERNANDES IDOF., FERNANDES JC., ALDRED VL., SANDOVAL MP., PUORTO G., THEAKSTON RDG., WARRELL DA. Snake bites by jararacuçu (Bothrops jararacussu): clinicopathological studies of 29 proven cases in São Paulo, Brazil. Q. J. Med, 1997, 90, 323-34.

19 MOTTA VT. Bioquímica clínica para laboratório: princípios e interpretações. Porto Alegre: Editora Médica Missau, 2003. 419 p.

20 OSHIMA-FRANCO Y., ALVES CMV., ANDRÉO FILHO N., GERENUTTI M., CINTRA ACO., LEITE GB., RODRIGUES-SIMIONI L., SILVA MG. Neutralization of the neuromuscular activity of Bothopstoxin-I, a myotoxin from Bothrops jararacussu snake venom, by a hydroalcoholic extract of Caseria sylvestris Sw. (Guaçatonga), J. Venom. Anim. Toxins incl. Trop. Dis., 2005, 11, 465-78.

21 OSHIMA-FRANCO Y., HYSLOP S., CINTRA ACO., GIGLIO JR., CRUZHÖFLING MA., RODRIGUES-SIMIONI L. Neutralizing capacity of commercial bothropic antivenom against Bothrops jararacussu venom and bothropstoxin-I. Muscle Nerve, 2000, 23, 1832-9. 
22 OSHIMA-FRANCO Y., LEITE GB., VALERIO AA., HYSLOP S., ESCARSO SHA., GIGLIO JR., PRADO-FRANCESCHI J., CRUZ-HÖFLING MA., RODRIGUESSIMIONI L. Rabbit antivenom efficacy against myotoxic and neurotoxic activities of Bothrops jararacussu venom and Bothropstoxin-I. J. Venom. Anim. Toxins, 2002, 8, 226-43.

23 QUEIRÓZ LS., SANTO NETO H., RODRIGUES-SIMIONI L., PRADOFRANCESCHI J. Muscle necrosis and regeneration after envenomation by Bothrops jararacussu snake venom. Toxicon, 1984, 22, 339-46.

24 SHERLOCK S. Drugs and Liver. In: SHERLOCK S. Diseases of the liver and biliary system. 7.ed. London: Blackwell, 1985: 304-33.

25 SILVEIRA KSO., BOECHEM NT., NASCIMENTO SMD., MURAKAMI YLB., BARBOSA AP., MELO PA., MORAES VLG., ROCCO PRM., ZIN WA. Pulmonary mechanics and lung histology in acute lung injury induced by Bothrops jararaca venom. Resp. Physiol. Neurobiol., 2004, 139, 167-77.

26 SOARES AM., RODRIGUES VM., BORGES MH., ESCARSO SHA., CUNHA OAB., HOMSI-BRANDEBURGO MI., GIGLIO JR. Inhibition of proteases, myotoxins and phospholipases $\mathrm{A}_{2}$ from Bothrops venoms by the heteromeric protein complex of Didelphis albiventris opossum serum. Biochem. Mol. Biol. Int., 1997, 43, 1091-9.

27 TEIBLER P., ACOSTA DE PÉREZ O., MARUÑAK S., RUIZ R., KOSCINCZUK P., SÁNCHEZ NEGRETTE M., MUSSART DE COPPO N. Local and systemic lesions induced by Bothrops alternatus venom (víbora de la cruz) of Argentine. Acta Toxicol. Argentina, 1999, 7, 7-10.

28 ZAMUNÉR SR., PRADO-FRANCESCHI J., CRUZ-HÖFLING MA., RODRIGUESSIMIONI L. Comparative myotoxic activities of bothropic venoms as assessed by enzymatic and histological assays. J. Venom. Anim. Toxins, 1997, 3, 160. 